\title{
The asymmetrical bank-client relationship Case of Algerian public banks
}

\author{
SENOUCI Kouider ${ }^{1}$ \& MERAD BOUDIA Mohammed Djamil ${ }^{2}$ \\ ${ }^{1}$ Senior Lecturer, Faculty of Economic, Tlemcen University, Algeria \\ ${ }^{2}$ Senior Lecturer, Faculty of Economic, Tlemcen University, Algeria
}

\begin{abstract}
:
Asymmetric information remains one of the most crucial problems in finance, though many works have been produced since the first writings of Akerloff, Spence and Stiglitz and many others. The inequality of getting information causes many problems to entreprises, because the responsible needs all information to solve these problems and decides what solution should fulfil the purpose in vew. In this context, the information and communication technologies (ICT) play a dominant role for the spreading of information to different users and researchers. The present work is articulated around two main parts. The first deals with the theoretical aspects of asymmetric information. The second is an empirical approach realised using a sample of questions in Algerian public Banks. All the questions deal with the impact of asymmetric information on the banking activity.
\end{abstract}

Key words: asymmetric information - Bank - Customer - relationship - risk.

\section{Introduction}

The development of the concept of information and information asymmetry through the various economic theories has not ceased to provide answers to the questions of various university researchers and users. The uninterrupted growth of information and communication technologies has tipped traditional patterns. The new technologies are clearly increasing the speed of information transmission. TAPSCOTT Don - CASTON Art (1994) insist on the importance of the revolution of information technologies ${ }^{1}$. REIX (2004) observed that it is necessary to have the essential knowledge to address the main problems posed to organizations by the use of information technology ${ }^{2}$. Detailed information on companies and market indicators can be obtained quickly and at very low cost. On the other hand, it is not clear that new technologies can eliminate all information asymmetries in financial markets. The relationship between the bank and the customer remains asymmetrical for ever, due to a lack of trust between the two parties. In the absence of sufficient information about the future, neither party can decide rationally. Therefore the commitment on any transaction only occurs by contract. However, the information provided to the contractors is often asymmetrical. In the absence of ethics, the agent takes advantage of his informational rent to the detriment of the principle. STIGLITZ applied this theory to insurance contracts. As a result of this work, Stiglitz was awarded the 2001 Nobel Prize in Economics for his contribution to the information economy. In order to comfort both parties, regulatory intervention is de facto required. This will allow for a certain transparency.

Despite this, the information remains imperfect (concept developed by AKERLOFF in 2004). In order to make informed choices you need information ${ }^{3}$.

In the light of the considerations raised, we pose the following problem: What is the nature of the risk that the bank must manage for the benefit of its customers? Our contribution focuses on the following elements:

Information and interests of the client; Management and evaluation of credit risk; Integrating of CSR into the bank-client relationship to alleviate the problem of information asymmetry; Case study: effect of information on the development of banking activity.

\section{2-Information and interests of the client:}

As evidence indicates, the present paragraph enlightens broadly and emphatically the most 
outstanding elements of information and interests of the client. They are mainly and namely as follows:

\section{2-1-Anti-selection and moral hazard}

The presence of transaction costs in financial markets partly explains why financial intermediaries are so important ${ }^{4}$. The information asymmetries associated with credit operations can be grouped into two categories, reflecting hidden information and action phenomena ${ }^{5}$. Information asymmetries lead to two types of problems: pre-transaction anti-selection and post-transaction moral hazard. Anti-selection refers to the fact that bad credit risks are most likely to be financed by loans, and moral hazard refers to the situation where the borrower engages in activities that are undesirable from the lender's point of view ${ }^{6}$.

\subsubsection{Anti-selection (adverse selection)}

Anti-selection is the problem created by asymmetric information before a transaction takes place. Antiselection occurs in a financial market when the borrowers most likely to lead to poor results (the riskiest) are those who are most actively seeking credit and who are most likely to obtain it and therefore to be selected.

Because of anti-selection, many risky loans are granted, but if lenders are too afraid of losing their money as a result, they may decide not to lend at all even though there are good potential borrowers among the candidates.

The economist George Akerloff ${ }^{7}$ (1970) has analysed the problem of anti-selection by touching on the functioning of the market. This characterization is known as the nightingale problem, and is illustrated in particular by the functioning of the used car market, where poor quality models are commonly presented. Potential buyers of second-hand cars are generally unable to change their quality; indeed, they cannot observe whether a particular model is a good-quality car or a nightingale that will give them constant trouble.

\section{Reducing anti-selection:}

The nightingale problem disappears in the absence of information asymmetry (MISHKIN Frederic and al. 2007) .

The reduction of anti-selection can occur from:

-The private production and sale of information:

The remedy for anti-selection in financial markets is to eliminate information asymmetry by providing agents holding funds with all the necessary details about individuals or firms seeking to finance their investment activities. One way of disclosing this information to savers is to entrust private companies with the task of collecting and producing the information that distinguishes between good and bad companies, and selling this information.

-Public regulation of information: Stowaways prevent the private market from producing enough information to eliminate all the asymmetries that lead to anti-selection. Financial markets can benefit from state intervention. The state could, for example, produce information that would allow investors to distinguish between good and bad companies, and provide it to the public at no cost. However, this solution would imply that the state makes a negative judgment on certain companies, a practice that would be politically difficult. The other possibility is for the state to control the securities markets in a way that encourages companies to disclose truthful information about themselves, so that investors can determine for themselves how good or bad those companies are.

-Financial intermediation: Private production of information and public regulation are decreasing but do not completely eliminate anti-selection in financial markets. Financial intermediaries play a role in financial markets comparable to that of second-hand car salesmen in that they help to resolve anti-selection. A financial intermediary, for example a bank, becomes an expert in producing information about companies (CASTEL M. et YANEL 1991) ${ }^{9}$; it is able to classify good credit risks and bad ones. It can then acquire funds from depositors and lend them to the right companies.

-Collateral and net assets: Anti-selection only affects the functioning of financial markets if the lender suffers a loss when the borrower defaults and is unable to repay the loan. The consequences of anti-selection can be reduced by collateral or guarantees. At this point the lender's losses are reduced if the borrower defaults. If the borrower defaults, the lender can sell the collateral and use the proceeds to offset losses on the loan.

The effects of credit market information: Lending bankers in the credit market have only imperfect knowledge of the risks associated with the loans they make. On the other hand, borrowers know perfectly well the probability of success of their project. There is therefore an asymmetry of information that will lead to anti-selection. Since risky borrowers have a demand for credit that is less elastic to interest rates, the bank involuntarily selects risky borrowers and is forced to raise its rates further. Not only were low-risk borrowers unable to find a way to finance their projects, but not all high-risk borrowers were able to 
get financing because credit was rationed; the market closed without being sold off (equality between supply and demand) ${ }^{10}$. Another way for financial institutions to manage anti-selection and moral hazard is to ration credit in two forms: the first is when a lender refuses to grant a loan of any amount to a borrower, and the second is when a lender is willing to grant credit but reduces it to an amount lower than that desired by the borrower. Financial institutions engage in the second type of credit rationing to protect themselves from moral hazard.

\section{-Alternative solutions to the problems of adverse selection, namely: signal and filtering.}

-Signal theory: Signal theory is based on the fact that information is unequally shared or asymmetric, with the managers of a firm having, among other things, more information than its fund providers. To do so, they use the signal, a financial decision that carries negative financial consequences for its initiator in the event that the signal proves to be erroneous. This theory, which highlights the importance of the credibility of the signal (hence the need for sanctions in the event of a lie), raises questions about investors' perception of any financial decision (and not just its objective scope) ${ }^{11}$.

-The filter: To solve the problem of adverse selection, the filter is used in the context of perfect and imperfect information.

a-filtering it in a perfect information frame: The agent receives the information and knows that it is perfect, true and certain. His personal filter can then determine according to his own utility function what is the best behaviour that offers the best result for him, since it is endowed with a substantive rationality. His behaviour may be different from that of another agent if he has another utility function. One agent prefers to save when the other has to pay off debts or invest and, therefore, the differences in utility at any given time determine the diversity of behaviour in the market and thus the very existence of the goods market (KENNETH J. Arrow 1987) ${ }^{12}$.

With the help of his rationality, the agent deciphers the information that comes to him from the outside and infers behaviour from it, without taking into account the behaviour of others.

\section{b- filtering it in a framework of imperfect information:}

The dominant model of corporate governance has sought to take greater account of the realism of practices: information that is difficult to obtain, complicated, missing and incomplete. In response, the informational filter of individuals is conceived as increasingly complex when information is imperfect due in particular to opportunism and the emergence of strategies linked to divergent interests between actors. In this context, it is essential to filter information that its quality is not assured: it depends on the transmitter, channels or noise emitted by other actors. As the issue of information is linked to that of exchange and coordination, recourse to the market entails information and communication costs (COASE Ronald $)^{13}$.

The importance of imperfect information: Joseph $\mathrm{E}$ Stiglitz and Carl E. Walsh (2004) ${ }^{14}$ have sometimes referred to the modern economy as the information economy. This is because advances in computer technology have greatly increased our ability to process information. But no matter how much information a person has, he or she is rarely satisfied. Not only is information imperfect, but different people have different information. Information is asymmetric. The fact that individuals and firms essentially make their decisions on the basis of imperfect information affects market behaviour in several ways. First, firms and individuals try to compensate for the lack of information.

\subsubsection{Moral Hazard:}

Moral risk is the problem created by information asymmetry after a transaction is completed. Moral risk in a financial market is the risk that the borrower will engage in activities that are considered undesirable (immoral) by the lender because they increase the risk of the project to which the loan is devoted and thus decrease the likelihood that the loan will be repaid. Because moral hazard increases the risk of loss, lenders may decide not to lend, even though the original project is good and even though borrowers may not actually want to increase the risk (MILGRON P et ROBERTS J. 1997) ${ }^{15}$.

Because they specialize in these tasks of reducing information asymmetry, financial intermediaries can pay interest to depositors or provide services to them while earning money (MISHKIN Frederic and al. 2007) ${ }^{16}$.

When there is moral hazard, the problem is to invite the agent who has private information to make an optimal decision for the uninformed individual. The problem is therefore different from that encountered in the case of anti-selection, where the uninformed 
individual has to select a good partner or a good product.

The influence of moral hazard on the financial structure of debt markets: Debt contracts are subject to moral hazard even taking into account the benefits that have been outlined above. A debt contract requires the borrower to pay a fixed amount, but allows the borrower to keep any profits above that amount, thus providing the borrower with an incentive to undertake investment projects that are riskier than those chosen by the lender. However, once the funds are paid to the contractor, the contractor could use them for purposes other than those related to the project. The lender therefore has an incentive to undertake a riskier investment using the money loaned to the entrepreneur because the gains would be very significant if the entrepreneur were successful. The lender, on the other hand, would be very annoyed if the entrepreneur used his money to finance the riskier investment.

Reduction of moral hazard in debt contracts: When the contractor himself is more exposed because his net assets are high, the moral hazard is greatly reduced because the borrower himself has a lot to lose. If the borrower commits more of his or her own money to the business, it becomes easier to grant a loan. As can be seen, net assets provide elements to reduce moral hazard, since the debt contract represents an incentive scheme. The higher the borrower's net assets, the greater the incentive for the borrower to behave in a way that corresponds to the lender's hopes and desires; under these conditions, the moral hazard associated with the debt contract is reduced.

\section{Monitoring and enforcement of protective} covenants: The more the lender is convinced that the borrower is not investing in a project that is riskier than the original project, the more profitable the loan of funds appears to the lender. The lender can ensure that the funds are used for the purpose for which they are intended. The lender takes the precaution of drafting a text that includes protective clauses associated with the debt contract in order to restrict the company's activities. Restrictive clauses in a credit agreement define cases where the borrower's failure to respect the objectives may result in the loan being forfeited and the obligation to repay it early. Protective covenants are intended to reduce moral hazard.

According to MISHKIN Frederic and al (2007), there are four types of protective clauses to achieve this objective, namely: clauses discouraging undesirable behaviour, clauses encouraging desirable behaviour, clauses preserving the value of collateral and finally clauses providing information ${ }^{17}$.

Financial intermediation: Banks have the possibility to exclude stowaways as long as they grant private loans. Private loans are generally not exchangeable, so that no other agent can intervene as a stowaway in the surveillance and enforcement of the protective clauses exercised by the intermediary. In this way, the intermediary alone receives the benefits of monitoring and control and thus contributes to reducing the moral hazard inherent in the debt contract. HAMBRICH J.G (1989) considers that banks enter into long-term relationships with borrowers but not with depositors, which implies the existence of an asymmetrical banking structure ${ }^{18}$.

\section{1-2-Interest of the client:}

Contracts are supposed to protect the people who signed them. However, the impossibility of establishing exhaustive contracts prevents a perfect harmonization of motivations. Incompleteness of contracts can thus give rise to opportunistic behaviour that will create uncertainty in the contractual relationship. The opportunist suggests a more sophisticated attitude of calculation than the classical hypothesis of personal interest (OUCHI W.G. and WILLIAMSON O.E, 1981) $)^{19}$. It characterizes the absence of honesty in transactions, the non-respect of the rules of the economic game, the search for selfinterest through cunning.

It should be noted that opportunism introduces the concept of time into the practice of exchanges; the question of behaviour (actual behaviour/expected behaviour) does not arise in the context of established relationships (GOMEZ P.Y 1996) ${ }^{20}$.

Opportunistic behaviour is therefore linked to limited rationality and incomplete information. Risks are the hazards that will weigh on the transaction and that can give rise to manipulation and distortion of information. The difficulty lies in the fact that this is not a behaviour that affects all individuals and that it is costly to recognize those who are opportunistic from those who are not.

The role of intermediation can therefore only be understood as a response to market imperfections and, in particular, the information asymmetries that characterise the credit market (DIAMOND D.W $1984)^{21}$. Intermediation is useless when there is market efficiency and symmetric information from different agents. Investors, in this context, are able to replicate 
all the financial services offered by intermediaries. Financing can take place directly on financial markets through securities issues.

Conflicts of interest:

A conflict of interest is a type of moral hazard that arises when an agent or institution pursues related objectives, i.e. multiple joint interests, and conflicts arise between them. The likelihood of conflicts of interest within financial institutions is particularly high when they provide related services. Potentially conflicting interests between these service offerings may lead a member of staff or the company to conceal misinformation. The analysis of information asymmetries helps us to measure the importance of conflicts of interest, their origin and the loss of economic efficiency they cause. Conflicts of interest should not be neglected because they substantially alter the quality of financial market information, increase problems of information asymmetry, and distort the mechanism for allocating funds to productive investment opportunities. Conflicts of interest undermine the efficiency of financial markets and the economy.

\section{3- Management and evaluation of credit risk:}

Risk is a possibility of harm that can be apprehended from a probability distribution based on chronicles. In finance, risk differs from uncertainty where the probability distribution is not available. There is a distinction between risk and uncertainty (KNIGHT Franck 1921$)^{22}$ : risk is measurable by an objective probability, whereas uncertainty corresponds to situations that are not measurable and therefore to a subjective probability. Credit risk management is another way of anticipating different contingencies and anticipating unpleasant surprises that may arise. As banks and financial institutions are obliged to give loans that will be repaid in full in order to have the highest gains, the economic concepts of anti-selection and moral hazard make it possible to analyse the principles adopted by financial institutions to reduce credit risk and make profitable loans (MOREAU Frank 2002) $)^{23}$.

The emergence of anti-selection in the markets for loanable funds because of bad credit risks (susceptibility to default on their loan) means that those who make the chain to borrow, i.e. those who are most likely to produce negative income are more likely to be selected. The riskiest projects pay more to borrowers, if they are successful, and they are therefore the most willing to borrow. However, they are clearly from the least desirable borrowers to those with a high probability of being unable to repay their loans (MISHKIN Frederic and al. 2007) ${ }^{24}$. The role of intermediation can only be understood in response to market imperfections, including information asymmetries in the credit market (CHIPPRI P.A. and YANELLE M.O 1996) ${ }^{25}$. BARTHELEMY Bernard and COURREGES Philippe (2004) emphasizes the following: better perception of risks, then economic reduction of their potential impacts, constitute a true management system, since the art of managing a company is to know how to take only those risks that are worthwhile ${ }^{26}$.

\section{The risk management process:}

Risk management is the set of tools, techniques and organizational arrangements for identifying, measuring and monitoring risks. A distinction is made between internal management and global management. The first relates to risks taken individually and according to their nature (market risk, liquidity risk, credit risk, etc.). Whereas global management is a holistic process, which involves consolidating all risks and taking into account their interdependencies.

Risk management is a logical process that generally consists of six steps:

Step 1: Identification of risks: Risks evolve with changes in the bank's internal and external environment. They must therefore be identified on an ongoing basis.

Step 2: Risk assessment and measurement: This consists of quantifying the probability of risk occurrence and the resulting losses. A good risk assessment will be a decisive factor in the choice of the institution.

Step 3: Analysis, decision and planning of measures: Only after analysis of the variables that give rise to the risk will measures be sought. A decision will then be made and the actions to be taken will be planned. Indeed, in the face of risks, and depending on their utility function and degree of risk aversion, financial institutions can use four alternative fundamental strategies:

- Avoid risk by avoiding the operations that generate it.

- Limit risk by setting limits that the bank will not allow itself to exceed. These limits can be expressed in terms of volume, value at risk, capital commitments or maximum losses.

- Transfer the risk by paying a premium that will allow the risk to be transferred in whole or in part. 
- Paying for the risk, i.e. bearing its cost directly out of own funds or reserves.

Step 4: Operational risk management: In this step, plans, strategies and means are implemented. Each risk is managed by the unit designated for this purpose.

Step 5: Risk monitoring: Over time, and depending on the circumstances, new risk exposures may emerge and information on the likelihood and significance of risks may be refined. Risk management requires regular monitoring of risk to ensure that the decisions taken are always optimal and that the limits set are always respected.

Step 6: Risk reporting: The reporting system is the logical outcome of the entire process. The results of risk management are assessed in reports that are sent to the bank's various responsibility centers (Executive Board, Board of Directors, Risk Committee, etc.).

The risk inspection function is responsible for ensuring that credit risks are properly reported (LAMARQUE Eric 2003) ${ }^{27}$.

3-Integrating CSR into the bank-client relationship to alleviate the problem of information asymmetry:

In order not to thwart the ethics of banking, there are new trends in project financing. As such, Corporate Social Responsibility (CSR) has been integrated into the bank-client relationship. The importance of the degree of integration only reassures stakeholders and reduces the informational asymmetry between the two parties. The financing of any economic activity takes into account a reliable technico-economic study reflecting the reality of the company. With the accelerated economic and social development of different nations and the relevance of NGOs and human rights organizations, the concept of corporate social responsibility (CSR) has already gained momentum in developed countries and has begun to be introduced in developing countries. CSR tends to define the responsibilities of companies towards their stakeholders. A donor needs to know exactly where its funds are going. In addition to economic and financial profitability, the project must have positive societal impacts. CSR is a concept that consists of integrating the social, environmental and economic concerns of companies into their activities and their interaction with stakeholders. It also means that companies contribute to improving society.

Ethics must exist everywhere and in any activity for more comfort of CSR (ARNSPERGER Christian, Van Parys Philippe 2003) ${ }^{28}$. Emmanuel REYNAULD (2006) considered employees as the most important stakeholder of the company that must be managed in an ethical and responsible way to improve the overall performance of the company ${ }^{29}$. In theoretical terms, the European definition leads to the conclusion that CSR is a voluntary concept $^{30}$; it should not be separated from business strategy and operations. The important aspect of CSR is the way companies interact with their internal and external stakeholders (employees, customers, neighbors, NGOs, public authorities, etc.).

In practical terms, CSR is about the voluntary integration by companies of their social, environmental and economic role ${ }^{31}$. It encompasses, for example, the overall quality of supply chains, subcontracting, the well-being of employees, the ecological footprint of the company. The exercise of CSR requires a good understanding of the company's environment, as well as respect for the balance of stakeholder interests. This concept is directly linked to the notion of sustainable development; of which it is the declination for the company. The relationship between this objective and the satisfaction of the company's stakeholders is, however, rather complex, especially since development does not depend exclusively on companies but on all economic agents (BADDACHE Farid 2004) ${ }^{32}$. The company accepts to have a social responsibility towards its members for a sustainable development (MERCIER Samuel 2004) ${ }^{33}$.

Within the framework of socially responsible investment (SRI), any long-term economic growth model must also respect people and their environment. The aim is to "meet the needs of current generations without compromising the ability of future generations to meet their own needs" (BALTHAZAR Bernard L $2006)^{34}$. Companies should avoid exclusion of actors who respect SRI principles (STEPHANY Didier $2003)^{35}$.

In Algeria, for example, financial costs are constantly increasing. The actions carried out, committed or to be carried out in the future for environmental preservation have benefited from investments made by the state or national companies. To this end, international financing has been mobilized as well as donations ${ }^{36}$ : Cement plants have devoted a total investment of 2324 million dinars for the fight against emissions of polluting discharges and asbestos cement units 266 million dinars for installations and dust removal.

To this end and in the context of bank financing, if the lender in its credit file study does not take into account CSR principles, it could jeopardize its funds and jeopardize them. These cases may occur in countries where NGOs play a very important role in guiding 
consumers in boycotting the purchase of certain products from certain suppliers or calling for the closure of factories that pollute the environment (for example, the closure of the Zahana cement factory in Sidi-Bel-Abbes Algeria for a certain period because of pollution).

4- Case study: effect of information on the development of banking activity

In the theoretical part, we have tried to highlight the problem of asymmetry of information in the bankclient relationship, while specifying the inequality in the distribution of information between agents, some actors are better informed than others about themselves but also about the economic context. Based on this research, we can say that economic theory has recognised the existence of informational asymmetry.
It is for this reason that an attempt was made to apply what the precursors in this field have brought to five Algerian public banks in the form of a survey to find out more in the field about the effects of information asymmetry on the bank-client relationship. To this end, we based ourselves on the hypothesis of the existence of asymmetry of information between the different structures of public banks firstly, secondly on the appearance of the problem of asymmetry of information as an obstacle for the bank's managers in their management actions and finally on the search for the best means to reduce the asymmetry of information. This work is carried out on the basis of using a survey to determine the causes of the asymmetrical bank-client relationship.

Brief overview of the five public banks included in the empirical study ${ }^{37}$ :

\begin{tabular}{|l|l|l|l|l|l|}
\hline Banks & BNA & BEA & CPA & BADR & BDL \\
\hline Head Office & Algiers & Algiers & Algiers & Algiers & Algiers \\
\hline Social capital & 150 billion da & 230 billion da & 48 billion da & 54 billion da & 36.8 billion da \\
\hline Date of creation & $13 / 06 / 1966$ & $01 / 10 / 1967$ & $11 / 03 / 1967$ & $13 / 03 / 1982$ & $30 / 04 / 1985$ \\
\hline $\begin{array}{l}\text { number of bank } \\
\text { branches }\end{array}$ & 216 & 120 & 211 & 293 & 152 \\
\hline
\end{tabular}

Activity of these banks: Banking production and financing of all sectors of activity.

\section{Human Resources Management in public banks and the effect of the asymmetric problem:}

The importance given to Human Resource Management (HRM) in the presence of information asymmetry is among Spence's "Job Market Signaling" work and is the opposite of Akerloff's adverse selection. Spence's work has been in the area of job market signals in the form of recruitment. And since the case of recruitment is studied in the presence of information asymmetry, training is seen as signals sent to avoid falling into adverse selection.

And since public banks are supposed to have the capacity to provide quality services, which are not directly observable (moral hazard), they make selections in recruitment based on continuous training.

In human resources management, these banks have made significant budgets available for the recruitment of university executives and for training, in order to adapt to the accelerated development of the banking system, which is constantly progressing, and especially to new banking technologies. Also, in the field of credit file studies, upgrading trainings were provided by Euro Meda to the various banks. Possible with the new working and analysis tools at the level of banks, the asymmetrical problem of information can be reduced either within the bank (hierarchy and services) or in the bank-client relationship.

Based on the survey developed, we tried to test what we discussed in the theoretical part.

\section{Results of the survey:}

Our questionnaire is intended for the bankers of the five public banks in the Tlemcen area (bank branches + regional branches):

\begin{tabular}{|l|l|}
\hline Designation & Bankers \\
\hline $\begin{array}{l}\text { Number of questionnaires } \\
\text { distributed }\end{array}$ & 68 \\
\hline Number of Responses & 62 \\
\hline
\end{tabular}

Quantified survey results and detailed analysis

Table A: Breakdown by gender

\begin{tabular}{|l|l|l|}
\hline Like & Staff & Rate \\
\hline Male & 38 & 61.29 \\
\hline Female & 24 & 38.71 \\
\hline Total & 62 & 100 \\
\hline
\end{tabular}

Table B: Breakdown of workforce by age

\begin{tabular}{|l|l|l|}
\hline Categories & Staff & Rate \\
\hline Under 25 years old & & \\
\hline From 25 to 30 years old & 6 & 9.68 \\
\hline From 30 to 45 years old & 36 & 58.06 \\
\hline 45 years old and over & 20 & 32.26 \\
\hline Total & 62 & 100 \\
\hline
\end{tabular}

Table C: Breakdown by level of education. 


\begin{tabular}{|l|l|l|}
\hline Education level & Staff & Rate \\
\hline Medium & & \\
\hline Vocational training & 4 & 6.45 \\
\hline Secondary & 4 & 6.45 \\
\hline Academic & 54 & 87.10 \\
\hline Total & 62 & 100 \\
\hline
\end{tabular}

Table D: Distribution by function

\begin{tabular}{|l|l|l|}
\hline Categories & Staff & Rate \\
\hline Runner & & \\
\hline Supervisors & 6 & 9.68 \\
\hline Executives & 56 & 90.32 \\
\hline Total & 62 & 100 \\
\hline
\end{tabular}

Table E: Breakdown of workforce by seniority.

\begin{tabular}{|l|l|l|}
\hline Seniority & Staff & Rates \\
\hline Less than 5 years old & 2 & 3.22 \\
\hline From 5 years to 10 years & 10 & 16.13 \\
\hline From 10 to 20 years old & 20 & 32.26 \\
\hline More than 20 years & 30 & 48.39 \\
\hline Total & 62 & 100 \\
\hline
\end{tabular}

In this part of the questionnaire concerning bankers, we wanted to reveal the target population:

A - By gender: We note that $61.29 \%$ of the bankers surveyed are male and only $38.71 \%$ are female.

B - According to age: On reading this table we notice that the highest age category is between 30 and 45 years old hence the rejuvenation of bank employees and especially with a dynamic university staff who can give new blood to the banking firm.

C - By level of education: It can be seen that $87.10 \%$ of the target population has a university level (a good sign for the banking sector), which gives a new dynamic to the banks. And especially that most of these academics are computer literate.

D - According to function: $90.32 \%$ of the target population are managers and $9.68 \%$ are supervisors holding sensitive positions in the bank, especially with the introduction of new payment systems.

E - According to seniority: The target population is mostly senior. $48.39 \%$ of them have more than 20 years' experience and $32 \%$ have between 10 and 20 years' experience, hence the reliability of the answers. Thus, two essential factors are present: experience and education.

Table 1: Can we really speak of a reliable B.I.S (Banking Information System) in Algeria?

\begin{tabular}{|l|l|l|}
\hline Answers & Staff & Percentage \\
\hline Yes & 26 & 41,93 \\
\hline No & 4 & 6,46 \\
\hline Not so much. & 32 & 51,61 \\
\hline Total & 62 & 100 \\
\hline
\end{tabular}

By asking this question, we wanted to measure the satisfaction of the bankers in the current B.I.S. Only

$41.93 \%$ of the surveyed population agrees with our questioning on the reliability of the B.I.S in Algeria.

Table 2: With the B.I.S., can we speak of information symmetry (perfect information) between the different services of the bank?

\begin{tabular}{|l|l|l|}
\hline Answers & Staff & Percentage \\
\hline Yes & 34 & 54,84 \\
\hline No & 28 & 45,16 \\
\hline Total & 62 & 100 \\
\hline
\end{tabular}

It can be seen that the symmetry of information between the different departments of the bank has not yet reached a significant stage. Only $54.84 \%$ of the target population speaks of perfect information.

Table 3: If so, why are there major financial scandals without the knowledge of those responsible?

\begin{tabular}{|l|l|l|}
\hline Answers & Staff & Percentage \\
\hline For not mastering the S.I.B. & 8 & 16.67 \\
\hline $\begin{array}{l}\text { For not mastering the } \\
\text { banking profession }\end{array}$ & 26 & 54.17 \\
\hline For complicity & 14 & 29.16 \\
\hline Total & 48 & 100 \\
\hline
\end{tabular}

Existence of financial scandals despite the existence of symmetry of information; $54.17 \%$ of the population surveyed replied that this was due to a lack of knowledge of the banking profession. A significant $29.16 \%$ said that these scandals are due to the complicity of bankers.

Table 4: What is your opinion on the hierarchical flow of information (up and down)?

\begin{tabular}{|l|l|l|}
\hline Answers & Staff & Percentage \\
\hline Good & 4 & 6.45 \\
\hline Average & 48 & 77.42 \\
\hline Wrong & 10 & 16.13 \\
\hline Total & 62 & 100 \\
\hline
\end{tabular}

We can see that the hierarchical flow of information does not work well. It is barely average (see importance of the rate: $77.42 \%$ ). Only $6.45 \%$ say it is good, while $16.13 \%$ of the population concerned say it is bad.

Table 5: Do you think that your line managers hold (hide) information that you don't have?

\begin{tabular}{|l|l|l|}
\hline Answers & Staff & Percentage \\
\hline Yes & 54 & 87.10 \\
\hline No & 8 & 12.90 \\
\hline Total & 62 & 100 \\
\hline
\end{tabular}

$87.10 \%$ of the population surveyed believe that line managers hide information from their subordinates, which causes a communication problem. No concerns of subordinates will be passed on to the line managers concerned. There will surely be a problem of information rent. 
Table 6: Can there be symmetry of information (perfect information) between the bank and the client using the B.I.S perfectly?

\begin{tabular}{|l|l|l|}
\hline Answers & Staff & Percentage \\
\hline Yes & 40 & 64.52 \\
\hline No & 22 & 35.48 \\
\hline Total & 62 & 100 \\
\hline
\end{tabular}

It can be seen that $64.52 \%$ of the targeted bankers think of the existence of information symmetry provided that the S I B is used perfectly.

Table 7: What are the strengths of the S.I.B.?

\begin{tabular}{|l|l|l|}
\hline Answers & Staff & Percentage \\
\hline Reliability of information & 16 & 25,81 \\
\hline $\begin{array}{l}\text { Effective means of } \\
\text { monitoring and control }\end{array}$ & 30 & 48,38 \\
\hline $\begin{array}{l}\text { Saving time and } \\
\text { productivity }\end{array}$ & 16 & 25,81 \\
\hline Total & 62 & \\
\hline
\end{tabular}

A large proportion of the bankers surveyed (48.38\%) believe that the strengths lie in effective monitoring and control (means of monitoring and control). In recent years, there has been a strengthening in the control of banking operations (see the audit and internal control systems installed at the level of public banks).

Table 8: What are the weak points of the B.I.S.?

\begin{tabular}{|l|l|l|}
\hline Answers & Staff & Percentage \\
\hline $\begin{array}{l}\text { In the event of a technical } \\
\text { failure, it is a total stop }\end{array}$ & 24 & 38,71 \\
\hline $\begin{array}{l}\text { Dependence of the human } \\
\text { being on the system }\end{array}$ & 18 & 29,03 \\
\hline Risk of data failure & 20 & 32,26 \\
\hline Total & 62 & 100 \\
\hline
\end{tabular}

$38.71 \%$ of the target population think that the weak points are in the case of technical breakdowns due to bankers' lack of mastery of IT tools, followed by the risk of data failure at $32.26 \%$ and human dependence on the system at $29.03 \%$. Thus the IT field remains the weak point of banks, it must be taken seriously and effectively in order to mitigate failures that may arise.

Table 9: Has the current B.I.S improved the bankclient relationship?

\begin{tabular}{|l|l|l|}
\hline Answers & Staff & Percentage \\
\hline Yes & 52 & 83,87 \\
\hline No & 10 & 16,13 \\
\hline Total & 62 & 100 \\
\hline
\end{tabular}

$83.87 \%$ of the population surveyed believe that the current SIB has improved the bank-client relationship. This logic, in our view, can reduce the asymmetry of information and contribute to even greater customer loyalty.
Table 10: What needs to be done for a perfect symmetrical bank-client relationship?

\begin{tabular}{|l|l|l|}
\hline Answers & Staff & Percentage \\
\hline For a loyalty white paper & 38 & 61,29 \\
\hline $\begin{array}{l}\text { For an integration of other } \\
\text { parameters (to be described) }\end{array}$ & 24 & 38,71 \\
\hline Total & 62 & 100 \\
\hline
\end{tabular}

$61.29 \%$ of the bankers surveyed are in favour of a white paper in order to build customer loyalty and raise the level of the bank-customer relationship. So the problem of customer loyalty remains the cornerstone of the banking business.

Table 11: According to your experience, can we really eliminate informational asymmetry (imperfect information) bank - customer?

\begin{tabular}{|l|l|l|}
\hline Answers & Staff & Percentage \\
\hline Yes & 26 & 41,93 \\
\hline No & 36 & 58,07 \\
\hline Total & 62 & 100 \\
\hline
\end{tabular}

Given the information problems that persist at the bank level $58.06 \%$ of the targeted bankers think that the information asymmetry Bank - Customer cannot be eliminated.

Table 12: If so, how?

\begin{tabular}{|l|l|l|}
\hline Answers & Staff & Percentage \\
\hline $\begin{array}{l}\text { To provide clients with } \\
\text { professional account } \\
\text { managers }\end{array}$ & 6 & 46,15 \\
\hline Customize services & 6 & 46,15 \\
\hline Other (describe) & 1 & 7,70 \\
\hline Total & 13 & 100 \\
\hline
\end{tabular}

The population answering "yes" to question 11 believes that the elimination of information asymmetry according to this survey can be achieved through two channels:

- personalization of services (at $46.15 \%$ ) for better client care.

- and making available to customers, professionals (at $46.15 \%$ ) who have a good understanding of banking operations and who know how to communicate to implement the bank's strategy.

Table 13: With information filtering, can we talk about perfect information?

\begin{tabular}{|l|l|l|}
\hline Answers & Staff & Percentage \\
\hline Yes & 36 & 58,06 \\
\hline No & 26 & 41,94 \\
\hline Total & 62 & 100 \\
\hline
\end{tabular}

We note that the problem of information asymmetry remains despite the use of information filtering. $58.06 \%$ of the target population think that filtering can solve the information problem, while $41.94 \%$ do not. Thus the first percentage is more important than the second and with the filtering of information from 
year to year, in addition to the evolution of the Algerian banking system, information will become more and more perfect.

Table 14: Is communication capable of reducing information asymmetry (imperfect information)?

\begin{tabular}{|l|l|l|}
\hline Answers & Staff & Percentage \\
\hline Yes & 58 & 93,55 \\
\hline No & 4 & 6,45 \\
\hline Total & 62 & 100 \\
\hline
\end{tabular}

From this question we have detected that the communication problem can really contribute to the reduction of information asymmetry. Effective communication can even eliminate the informational rent practiced by some agents, the rate of $93.55 \%$ implies it to us.

Table 15: With the use of a modern BIS and customer loyalty, can a symmetrical bank-tocustomer relationship be achieved?

\begin{tabular}{|l|l|l|}
\hline Answers & Staff & Percentage \\
\hline Yes & 60 & 96.77 \\
\hline No & 2 & 3.23 \\
\hline Total & 62 & 100 \\
\hline
\end{tabular}

$96.77 \%$ of the target population believe that by using a modern SIB and customer loyalty, a symmetrical Bank-Customer relationship can be achieved. This evolution of the SIB avoids the conflicts of interest that have been constantly arising in recent times (no room for opportunists).

Table 16: If so, can we talk about banking risk?

\begin{tabular}{|l|l|l|}
\hline Answers & Staff & Percentage \\
\hline Yes & 36 & 60 \\
\hline No & 18 & 30 \\
\hline Don't know. & 6 & 10 \\
\hline Total & 60 & 100 \\
\hline
\end{tabular}

We note that credit risk remains in spite of the solutions provided and the means used, since 60\% believe that bank risk still remains.

Table 17: In the case of perfect information, is the risk (whatever its nature) controllable?

\begin{tabular}{|l|l|l|}
\hline Answers & Staff & Percentage \\
\hline Yes & 52 & 83,87 \\
\hline No & 10 & 16,13 \\
\hline Total & 62 & 100 \\
\hline
\end{tabular}

We note that $83.87 \%$ of the target population see that the risk, whatever its nature, can be controlled provided that the information is symmetrical and perfect.

Table 18: If so, is the banker really obliged to take real guarantees to protect himself from the risk of non-reimbursement?

\begin{tabular}{|l|l|l|}
\hline Answers & Staff & Percentage \\
\hline Yes & 42 & 80.77 \\
\hline
\end{tabular}

\begin{tabular}{|l|l|l|}
\hline No & 10 & 19.23 \\
\hline Total & 52 & 100 \\
\hline
\end{tabular}

Despite the control of risk in the presence of information symmetry, $80.77 \%$ of the bankers surveyed are in favour of taking out a mortgage (collateral security). Only $19.23 \%$ of this population are in favour of allocating unsecured commitments.

Table 19: Otherwise, and in the event of client default, whose fault is it?

\begin{tabular}{|l|l|l|}
\hline Answers & Staff & Percentage \\
\hline At the SIB & 8 & 26,67 \\
\hline To the banker & 12 & 40,00 \\
\hline Other (describe) & 10 & 33,33 \\
\hline Total & 30 & 100 \\
\hline
\end{tabular}

We can see that $40 \%$ of the bankers who were in favour of granting credit without taking out a mortgage, blame the bankers in case of customer default and 26.67 blame the SIB and 33.33 blame other phenomena. In this case the Flair and the professionalism of the banker play a crucial role in the decision to grant credit, that is why the mistake is his fault.

Table 20: With the existence of a banking culture on the part of customers, can the problem of mistrust be eliminated?

\begin{tabular}{|l|l|l|}
\hline Answers & Staff & Percentage \\
\hline Yes & 46 & 74,19 \\
\hline No & 16 & 25,81 \\
\hline Total & 62 & 100 \\
\hline
\end{tabular}

It can be seen that 74.19 per cent of the target population see that the problem of mistrust can be reduced provided that there is a banking culture on the part of the customers, and the rest (29.81 per cent) see the exact opposite.

Table 21: Have the Bank of Algeria's prudential rules reduced the problem of imperfect information?

\begin{tabular}{|l|l|l|}
\hline Answers & Staff & Percentage \\
\hline Yes & 48 & 77,42 \\
\hline No & 14 & 22,58 \\
\hline Total & 62 & 100 \\
\hline
\end{tabular}

It can be seen that 77.42 per cent of the targeted bankers think that the prudential rules of the Bank of Algeria have reduced the problem of asymmetric information and 22.58 per cent see the opposite. We see that the first answer is more logical and what we see on the ground is the best evidence.

Table 22: Have the prudential rules of the Bank of Algeria brought confidence to clients, especially after the Khalifa Bank and BCIA Bank scandals?

\begin{tabular}{|l|l|l|}
\hline Answers & Staff & Percentage \\
\hline Yes & 46 & 74,19 \\
\hline No & 16 & 25,81 \\
\hline Total & 62 & 100 \\
\hline
\end{tabular}


$74.19 \%$ of the target population believe in the effectiveness of the Bank of Algeria's prudential rules. The public banks apply prudential rules properly, which is why none of these banks have had problems. Private banks have failed to comply with banking rules, which has cost them their bankruptcy in recent years.

Table 23: Have the new risk measures (the Basel rules) affected the bank-client relationship?

\begin{tabular}{|l|l|l|}
\hline Answers & Staff & Percentage \\
\hline Yes & 50 & 80,65 \\
\hline No & 12 & 19,35 \\
\hline Total & 62 & 100 \\
\hline
\end{tabular}

On the question of the new risk measures (the Basel rules), $80.65 \%$ of the bankers surveyed believe that these measures will have an impact on the bankclient relationship. Both parties were reassured by the compliance with banking regulations.

Table 24: Will Algeria's application of the new risk measures make the financial and banking sectors more comfortable?

\begin{tabular}{|l|l|l|}
\hline Answers & Staff & Percentage \\
\hline Yes & 52 & 83,87 \\
\hline No & 10 & 16,13 \\
\hline Total & 62 & 100 \\
\hline
\end{tabular}

$83.87 \%$ of the target population believe that Algeria's implementation of new risk measures will strengthen the banking and financial sectors. These measures have become universal and avoid different risks in the event of problems.

From the practical part, we have deduced the following: In order to improve the position of stateowned banks in the banking market, the powers that be must pay particular attention to the following aspects:

- Development of the B.I.S to improve the quality of banking services, avoid errors and minimize the problem of information asymmetry;

- Taking into account the fundamental principles of CSR within the framework of the various financing schemes;

- Opening up the capital of each bank;

- Upgrading training with foreign banks;

- Development of the financial market;

- Speed in the execution of banking operations with foreign countries;

- Setting up a live white line on credit for the development of customer loyalty;

- Evolving the market for banking skills;

- Encouragement and reconsideration of banking skills to avoid massive departures, especially of competent executives to other banks or other sectors;

- Controlling financial gambling;
- Reviewing the legal system and in particular the penal code (in order to reduce the penalties for fraudulent activities);

The recent financial crashes involving bankers have led to high-profile criticisms and legal grievances;

- Favour risk taking (creation of risk tolerance mechanisms to evolve); - The prudential regime in Algeria is evolving, it must be adapted to the current universal measures.

\section{Conclusion:}

Information is the best indicator that enables the bank to make its choices in terms of human resources and investments. If the bank wants to increase its profitability, it is always confronted with the informational problem, the degree of solution of which is measured according to its capacity to adapt to new banking technologies. In order to obtain the desired information and to face the competition, the institution must imperatively collect as much data as possible on potential competitors and this for the implementation of a strategy that will enable it to impose itself on the market. In other words, to be in a position of aggressiveness in the commercial field. The role of the customer is important in this relationship. Since the customer has only some incomplete information about the bank, it is the bank's duty to disseminate the information as much as possible as part of a communication strategy capable of retaining existing customers and attracting new ones.

\section{References :}

[1] Tapscott Don - CASTON Art, «L'entreprise de la deuxième ère, la révolution des technologies de l'information ", édition Dunod, (traduit par Anne Collas), Paris, 1994.

[2] Reix Robert «Systèmes d'information et management des organisations ", 5 édition, édition Vuibert, Paris, septembre 2004.

[3] STIGLiTZ J.E -WALSH Carl E. «Principes d'économie moderne » 2éme édition, édition De Boeck, 2004.

[4] GETTLER Mark, "financial structure and aggregate economic activity: an overview" journal of money, credit and banking 20 (1988) p.559-588.

[5] CHIPPRI P.A. et YANELLE M.O (1996), «le risque bancaire; un aperçu historique » Revue d'économie Financière $n^{\circ} 37$ page 97 111.

[6] MISHKIN Frederic, BORDES Christian, HAUTCOEUR Pierre-Cyrille and LACOSSE- 
LABARTHE Dominique, «Monnaie, banque et marchés financiers 8eme édition public par Pearson Education France 2007 », pp. 243244.

[7] AKERLOFF George, «The market for lemons: quality uncertainly and the market mechanism "Quartirly journal of Economics 84-(1970) p. 488.500.

[8] MISHKIN Frederic, BORDES Christian, HAUTCOEUR Pierre-Cyrille and LACOSSELABARTHE Dominique, "Monnaie, banque et marchés financiers 8eme édition public par Pearson Education France, 2007 » page 209.

[9] CASTEL M. et YANEL (1991), «la nouvelle intermédiation, développement des marchés et financement des entreprises» revue d'économie financière, $\mathrm{n}^{\circ} 16$ p.41-61.

[10] STIGLITZ Joseph E - WEISS A. (1981) "Credit rationing in markets with imperfect information", the American economic Review 1981 vol. 71 n$^{\circ} 03$ p.93-410.

[11] SPENCE Michael, "Signaling in Retrospect and the Informational Structure of Markets", June 2002.

[12] COASE Ronald, (1937), «the nature of the firm » economic, november 1973 N.S. French Translation (1987)." la nature de la firme" revue française d'économie, $\mathrm{n}^{\circ} 11$ p.133-163.

[13] COASE Ronald, (1937), «the nature of the firm » economic, november 1973 N.S. French Translation (1987)." la nature de la firme" revue française d'économie, $\mathrm{n}^{\circ} 11$ p.133-163.

[14] STIGLITZ Joseph E - WALSH Carl E, «Principes d'économie moderne » 2emeedition de Boeck université, 2004, p.328.

[15] MILGRON $P$ et ROBERTS J. «Economic, organisation \& management », De Boeck et Presses Universitaires de Grenoble Bruxelles, 1997.

[16] MISHKIN Frederic, BORDES Christian, HAUTCOEUR Pierre-Cyrille and LACOSSELABARTHE Dominique, op.cit, page 214.

[17] MISHKIN Frederic, BORDES Christian, HAUTCOEUR Pierre-Cyrille and LACOSSELABARTHE Dominique, op.cit, page 219.

[18] HAMBRICH J.G., " Financial Intermediation, Delegated monitoring and long term relationships" Journal of banking and finance, vol 13, page 9-20, (1989).

[19] OUCHI W.G. and WILLIAMSON O.E, 1981: the Market and hierachies and visible hand, perspectives » in A, van de Ven et W.F Joyce perspectives ou organisation design and behaviour, Johen wiley and sensp.347-369.
[20] GOMEZ P.Y., le gouvernement de l'entreprise, Paris, Inter Editions, 1996.

[21] DIAMOND D.W, « financial intermediation and delegated monitoring » review of economic studies, vol 51 p.393-163, 1984.

[22] KNIGHT Franck «Risk and uncertainly », 1921.

[23] MOREAU Frank, " comprendre et gérer les risques » édition d'organisation, 2002.

[24] MISHKIN Frederic, BORDES Christian, HAUTCOEUR Pierre-Cyrille et LACOSSELABARTHE Dominique, opcite, page 266.

[25] CHIPPRI P.A. et YANELLE M.O, « le risque bancaire ; un aperçu historique » Revue d'économie Financière $n^{\circ} 37$ page 98 , 1996.

[26] BARTHELEMY Bernard - COURREGES Philippe, «Gestion des risques : méthode d'optimisation globale», 3 édition, édition D’Organisation, Paris, 2004.

[27] LAMARQUE Eric "Gestion bancaire", Edition Pearson Education, France, année 2003, page 134 .

[28] ARNSPERGER Christian, Van Parys Philippe, «Ethique économique et sociale», édition La découverte, Paris, 2003.

[29] REYNAULD Emmanuel "Le développement durable au coeur de l'entreprise", Ed.Dunod, France, 2006, p.86.

[30] https://youmatter.world/fr/definition/rsedefinition/Definition of CSR by the European Union (Date of visit: 02/05/2020).

[31] https://youmatter.world/fr/definition/rsedefinition/Définition of CSR by the European Union (Date of visit: 02/05/2020).

BADDACHE Farid, « Entreprises et ONG face au développement durable: l'innovation par la coopération », Edition l'Harmattan 2004.

[33] MERCIER Samuel, «L'éthique dans les entreprises, repères », édition $\mathrm{La}$ Découverte, 2004, p.11.

[34] BALTHAZAR Bernard L, «le développement durable face à la puissance publique» édition l'Harmattan, 2006.

[35] STEPHANY Didier, «Développement durable et performance de l'entreprise ", édition Liaisons, Paris, 2003, p. 407. 
[36] Algerian Ministry of Land Use Planning and the Environment, Report on the state and future of the environment «general public version year 2000 page 101-102.

[37] Information taken from the websites of these banks. 